\title{
BUSINESS CASE ANALYSIS FOR RAPID PRODUCTISATION
}

\author{
Tuomo Kinnunen, University of Oulu, Finland \\ tuomo.kinnunen@oulu.fi \\ Kai Hänninen, University of Oulu, Finland \\ kai.hanninen@oulu.fi \\ Harri Haapasalo, University of Oulu, Finland \\ harri.haapasalo@oulu.fi \\ Hanna Kropsu-Vehkaperä, University of Oulu, Finland \\ hanna.kropsu-vehkapera@oulu.fi
}

\begin{abstract}
Purpose The objective of this study is to construct the procedure of business case analysis for rapid productisation. The paper studies the practice of business case analysis to aid collaborative decision making between product management and sales management.

Design/Methodology The research is qualitative and constructive in nature. We studied relevant literature and conducted an exploratory case study. Primary data was collected by semi-structured interviews. Business case analysis procedure for rapid productisation is constructed based on the literature study and the interview data analysis.

Findings $A$ state of the art practice of analysing rapid productisation opportunities is described. Such an analysis includes estimating and calculating revenue and costs, and checking strategic fit. Especially it includes considering the importance of the customer and the sales case in the revenue side, and project cost and resource reallocation cost. In addition, cost structure and market potential are estimated for the items that decided to include into global portfolio.

Originality/Value This study provides insight of the co-operation between sales, $R \& D$ and product management in building business case for rapid productisation. The results of the study are applicable for benchmarking similar industrial practices. The study contributes to the research of order delivery process and new product development in the area of rapid productisation.
\end{abstract}

Keywords: Business case analysis, productisation, rapid productisation

\section{INTRODUCTION}

To succeed in competition, companies need to offer products and services which meet the diverse needs of customers and market (Ulrich and Eppinger, 2008; Henard and Slymanski, 2001). An efficient way to provide wide product portfolio is mass customisation, which relies heavily on configurable and modular products (Hvam et al., 2008; Kratochvi'1 and Carson, 2005). However, needs may evolve and new opportunities rise after products are launched. In case of modular product structure, companies could respond by changing or redesigning product modules on the fly. The context of this study is limited to the process of introducing 
that kind of changes in existing products to serve sales and order-delivery process. The focus of the study is in business case analysis for such rapid productisation.

Business case analysis is common practice for analysing and defining potential investments (Keen and Digrius, 2002; Randall et al., 2012). Its main goal is to demonstrate, in a rational way, the true business value of potential investment. According Keen and Digrius (2002) business case analysis describes business reasons why or why not specific investment options should be selected. Ultimately, productisation is driven by intent to create successful products and profitable business. The same drivers must be employed in business case analysis for productisation (Kinnunen et al., 2011).

Rapid productisation is widely utilised industrial practice especially in business to business companies. Typically, managers describe rapid productisation as an ad-hoc procedure which may disturb other business processes but is necessary for satisfying a customer and getting a new order. Compared to incremental product development (e.g. Gautam and Singh, 2008), rapid productisation as a customer-initiated and sales-driven process comes up unexpectedly, necessitates fast reaction and decision-making, and may not necessarily settle on the product portfolio. The more systematic procedure for rapid productisation could provide benefits and even competitive advantage for some companies (Hanninen et al., 2013). Literature does not recognise any holistic framework to recognise and analyse opportunities of rapid productisation. This clearly indicates a gap between literature and practice.

The aim of this study is to construct a framework and procedure of business case analysis for rapid productisation. The aim is divided to two research questions:

RQ1: How does business case analysis for rapid productisation differ from the analysis for new product development?

RQ2: How should business case be constructed in rapid productisation?

To fill the gap in literature the research questions will be answered by an exploratory case study. At first, relevant literature was studied in the fields of productisation and business case analysis to synthesise the theoretical frame for the study. Then, the case study was designed and primary data was collected by interviewing industrial experts involved and interested on this area. Then the data was analysed and the findings were discussed. Finally, we conclude the study by summarising the main results and findings. In our study, literature creates the framework but research questions are finally answered through empirical data.

\section{LITERATURE STUDY}

In a simplified matter, each product goes through two types of processes during its lifecycle; the product process and the order-delivery process. The product process includes new product introduction, product development, product maintenance and marketing processes while the order-delivery process consists of five phases: sales, procurement, manufacturing, delivery and service or maintenance (Saaksvuori and Immonen, 2008). The product process, the product creation process and the new product development process are concerned as synonyms with the productisation process in this study. Productisation is understood as a commercial function by which a company creates and updates its offering to respond a market opportunity and need. While the essence of any product is to satisfy customer needs or solve a customer problem, the purpose of productisation emphasise creating a tangible, 
repeatable offering which is efficient to produce and deliver and easy to sell, buy and use (Hietala, 2004; Simula, 2008).

The concept of rapid productisation is not yet well established in literature. Thus the definition of rapid productisation requires critical examination from two different process viewpoints. At first, the productisation process defines, designs and develops new products to the product portfolio (Ulrich and Eppinger, 2008). Secondly, the order-delivery process which defines how individual products are sold, manufactured and delivered to the customer, and maintained after sales (Chung et al., 2007; Saaksvuori and Immonen, 2008). Within this viewpoint, it may be beneficial discuss about stock and delivery items instead of products in general.

\section{Business case analysis in new product development}

New product development (NPD) is a key process for companies in seeking business success. Strong business-orientation is very apparent in NPD literature for example through gate criteria (Carbonell-Foulquie et al., 2004; Hart et al., 2003; Ronkainen ,1985). Typically, the starting phase of an NPD process is employed to both screen out the ideas with weak business potential and prioritise ideas with strong business potential. For example, Cooper (2001, 2007) describes the first NPD phase as scoping which contains preliminary market, technical and financial assessment as well as a rudimentary quick check of the business rationale and financial prospects of the project. Similar issues may be checked preceding the formal NPD process. Koen et al. (2001) proposes business case development during front end of innovation based on estimates of market potential, customer needs, investment requirements, competitor assessments, technology unknowns and overall project risk.

Business case is prepared during early phases of NPD to aid decision-making whether to invest resources for a development project (Otto and Wood, 2001). According Cooper (2001) the business case has three main components:

1) Product and project definition. Whom the product will be targeted at and what the product will be? Define benefits, features, and design requirements of the product.

2) Product justification. Why should a company invest in a project? It includes a review of financial, profitability and risk considerations. Also nonfinancial considerations, such as strategic rationale, competitive advantage, leverage and market attractiveness, should be included.

3) Project plan. How and by whom the path from development to launch is taken? It may be formulated as a critical path plan including schedule, the launch date and required resources - money, people, and equipment.

An important precondition for business case analysis is the existence of past financial information or analogous product data. Otherwise, the data must be extrapolated from a similar or analogous product, or rough estimates of product layouts. The cost data must be established considering the marketplace: e.g. unit costs and sales volume curves, dependence on other products or systems of the customers. (Otto and Wood, 2001).

Business case analysis in new product development may be too laborious and extensive to be used in rapid productisation. All the required data for different business case elements, namely market assessment, technical assessment, strategic fit and financial analysis, might 
not be available or not relevant (Kinnunen et al., 2011). For example, rapid productisation does not include thorough technical assessment because totally new technologies are too risky to productise rapidly, uncertainties must be manageable and technical solution must be defined quickly. Market assessment for rapid productisation is more sales-driven excluding a thorough market study. However, customer value may be evaluated similarly, and potentially market assessment provides similar outcome data. Strategic fit must be straight-forward to check quickly in case of rapid productisation. Finally, financial analysis is quite similar in both cases since it includes calculating and synthesising financial value into few key business performance indicators, such as return of investment (ROI) and net profit.

Instead of NPD business case analysis, rapid productisation business case analysis may be more similar to business consideration during the front end or the very first phase of NPD process. E.g. Cooper (2001) defines that as scoping phase which includes issues such as to check any market prospects, potential and requirements; technical feasibility, solutions and risks. Still, NPD literature does not provide any means to analyse a sales case or evaluate an order from either a customer or a company viewpoint.

\section{Order delivery process and rapid productisation}

Companies' current customer order point (COP) and order delivery process set the context for rapid productisation (Hvam et al., 2008). Rapid productisation does not fit all kind of delivery modes. In case of engineer-to-order delivery mode, all delivered products are productised or tailored for customers and rapid productisation is not a necessary option. In contrary, the make-to-stock delivery mode focus on efficient operations with existing stock items excluding any new specifications for orders (Chung et al., 2007). Thus rapid productisation is not a meaningful option for companies which current delivery mode is make-to-stock. Nevertheless, rapid productisation fits for the companies that have adopted modular product structure and use the configure-to-order delivery mode. In that mode products are built from standard parts and modules, and possible variants are specified by a configurator according predefined configuration rules (Hvam et al., 2011). If available configurations do not satisfy customer rapid productisation can be initiated to redesign or change existing modules to meet customer needs. In addition to productisation challenges this is an exception case for sales and current order-delivery process.

From order delivery process viewpoint, rapid productisation cases could be processed by order partitioning and hybrid mode of product delivery (Rafiei and Rabbani, 2011) or by bringing forward the customer order point (COP) from the current mode of delivery, e.g. from variant selection to configure to order (e.g. Hvam et al., 2008) Each order which include rapid productisation increases product variety from the order delivery viewpoint. Increased variety may be necessary to keep customers satisfied and to increase sales. However, it may disturb the normal order delivery process and include hidden costs related to the process. Thus, complete picture of the costs and benefits of variety should be known to assess the true profitability of rapid productisation (Ward et al., 2010) An example of case evaluation including order delivery process issues, namely variety cost-benefit calculator, is described by Ward et al. (2010). 


\section{METHODOLOGY}

This research is a qualitative case study in nature. The study applies an explorative and constructive research approach. The research process is illustrated in figure 1.

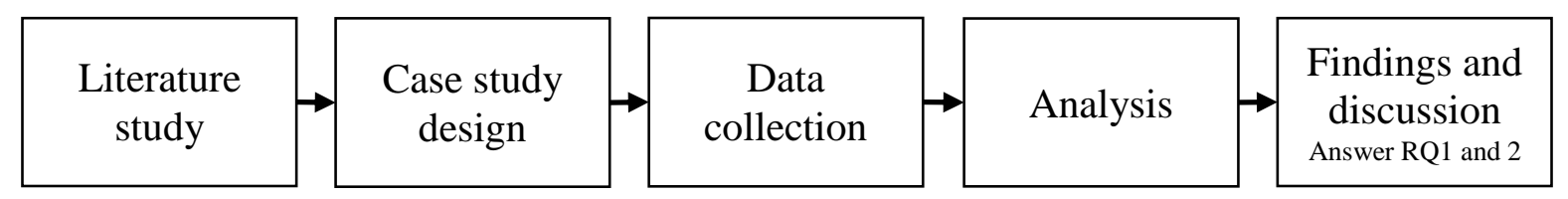

\section{Figure 1. The research process}

Case study design included creating a semi-structured interview questionnaire. The questionnaire was sent in advance to the interviewees to aid their preparing. The data was gathered through semi-structured interviews. Seven highly-experienced business managers engaged to rapid productisation were interviewed in six different companies. Interviews were recorded and transcribed to ensure thorough analysis. The transcriptions and interview summaries were sent to the interviewees to correct any misunderstandings. The interview data was collected during August 2011. In addition to the interview data and literature study, also secondary data was collected including business case documentations in two companies, discussions with experts and meeting minutes.

The interview data was analysed to provide a picture on rapid productisation business case in general and piece-by-piece as perceived by company managers. The secondary data sources were used to enhance understanding, support analysis and validate findings.

\section{RESULTS AND ANALYSIS}

The results are described by presenting relevant excerpts from the interview data. Table 1 . provides managerial perceptions on business case in general and go through in a more detailed way one of the key issues of any business case that is named as profitability analysis. 
Table 1. Managers' perceptions on business case and profitability analysis

\begin{tabular}{|c|c|}
\hline Issue & Excerpts from interview data \\
\hline $\begin{array}{l}\text { Perceptions } \\
\text { on business } \\
\text { case }\end{array}$ & $\begin{array}{l}\text { A) "It is a document" - "Combined with an offer business case indicates an } \\
\text { acceptable price" } \\
\text { B) "Business case becomes after calculating monetary value. Otherwise it is } \\
\text { a mere case." } \\
\text { "It is an analysed and documented team effort to aid managerial decision } \\
\text { making" } \\
\text { C) "Business case is a payback plan." - "Business case is done for the } \\
\text { company in collaboration between a product manager and a sales } \\
\text { representative. Sales intend to make a deal and their task is to calculate } \\
\text { break-even point of a sales case. Product managers intend to create a } \\
\text { commercial product and their task is to consider business case for the } \\
\text { solution. } \\
\text { D) "Business case consists of two sections: sales plan and cost plan. Sales } \\
\text { plan includes product sales during its predicted lifecycle and impact on } \\
\text { sales of other products. Cost plan includes costs " } \\
\text { E) "It is a justification for why to initiate a case. They are used for } \\
\text { prioritisations." }\end{array}$ \\
\hline $\begin{array}{l}\text { Profitability } \\
\text { analysis }\end{array}$ & $\begin{array}{l}\text { A) "As a part of price determination, profitability is a type of NPV (net } \\
\text { present value) calculation " - "A customer variant is not always } \\
\text { profitable. It may be necessary to make it in order to win a big deal where } \\
\text { the benefit comes standard blocks." } \\
\text { B) "Profitability assessment depends on the size of the project and the } \\
\text { customer." - "Calculation can be based an internal price compared to the } \\
\text { invoiced price and related costs." } \\
\text { C) "For customer variant requests we have a good formula for calculating } \\
\text { cost of changes and implementation lead time." - "Finance and Control } \\
\text { organisation provides manufacturing cost and total cost of products." - } \\
\text { "In negotiations the profitability is calculated quite efficiently by Sales } \\
\text { Simulation system which collects fact-based information from different } \\
\text { places." } \\
\text { D) "Globally defined, cost-based transfer prices are the starting point for } \\
\text { pricing by a sales team." } \\
\text { "Depending on the state of negotiations, certain products may take a loss } \\
\text { and certain products may make profit in the same deal. Finding out the } \\
\text { profitability of an individual deal, sales item or product in the global } \\
\text { business may be challenging." } \\
\text { E) In that case, a sales representative assesses whether marginal income is } \\
\text { adequate. Typically it is very short profitability analysis focusing only to } \\
\text { the project in hand." } \\
\text { F) "It is a pretty basic business thing to consider the expenses and income." }\end{array}$ \\
\hline
\end{tabular}

Managers perceive business case as

- being a document and justification for the case

- aiding decision-making

- including essentially calculation of monetary value 


\section{Proceedings of 2013 International Conference on}

TIM Technology Innovation and Industrial Management

29-31 May 2013, Phuket, Thailand

The perceptions on business case are quite consistent with our findings from literature. Instead, profitability analysis seems to vary more from a company to other. This may illustrate the fact that rapid productisation concerns different kind of changes in different products. An interesting point is the co-operation between sales representatives and product management. They may form a core team related to business case analysis in rapid productisation.

The relevant quotations on delivery capability and product portfolio consistency issues are presented in Table 2.

Table 2. Business case issues related to rapid productisation

\begin{tabular}{|l|l|l|}
\hline Issue & Excerpts from interview data \\
\hline Delivery & A) "Delivery organisation is responsible for deliveries. Assessing team has always \\
& someone involved from that organisation."
\end{tabular}

Delivery capability is a crucial element behind a credible business case analysis for rapid productisation since the customer is expecting to know the delivery time. Nevertheless, the research data indicates that it may not belong to the analysis. Thus, delivery information may be provided by a separate delivery capability analysis or delivery project plan. Consistency with the product portfolio instead seems to be an essential part of business case analysis that must be included. 


\section{Proceedings of 2013 International Conference on}

TIM Technology Innovation and Industrial Management

29-31 May 2013, Phuket, Thailand

Productisation has strategic role in most companies, and product creation includes always risks. Table 3. presents quotations on these nonfinancial considerations.

Table 3. Strategy and risk considerations in rapid productisation

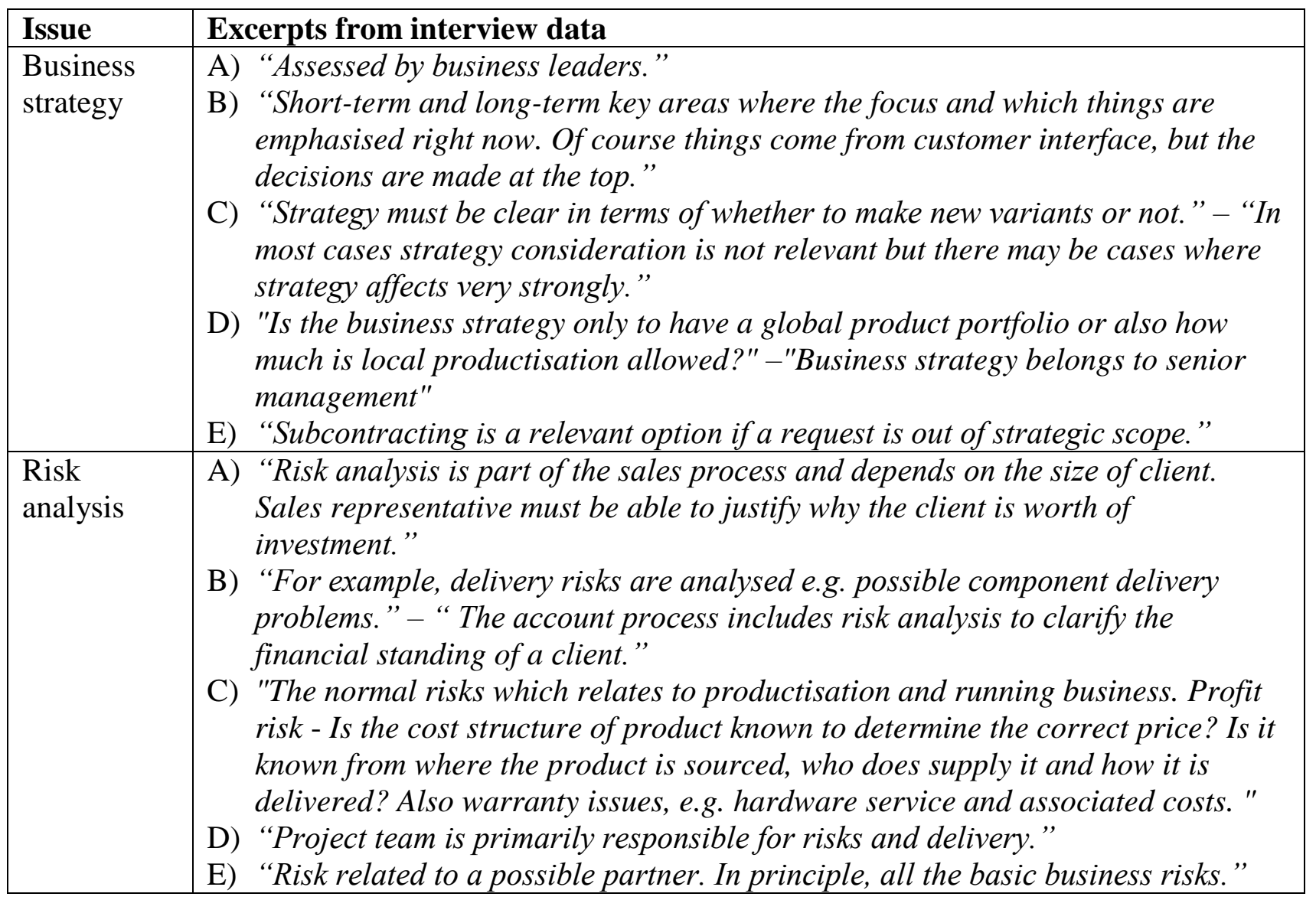

Strategic discussion has at least two levels related to rapid productisation. In the higher level, rapid productisation is either decided to accept or not as a business practice. This must be clear for sales representatives. In the lower business case level, strategic fit need to be considered with each rapid productisation business case. A common understanding seems to be that mostly the strategy is not an issue in business case analysis but potentially there may be cases where it is a crucial issue. Strategy consideration may affect strongly to the portfolio analysis, without strategic fit the case may never end up to the portfolio.

Although risks are always present in productisation, the research data indicates that they may not belong to the business case analysis as an individual element. Business case itself can be seen as a tool to manage business risks since it predicts business consequences of the case including cost and revenue estimations.

\section{FINDINGS AND DISCUSSION}

Business case is such a generic concept which any business-minded manager can produce, understand and utilise in decision making. Typically, business cases analysis practises are applied for the company specific needs and the practises vary a lot e.g. the level of formality, 
is it personal or team effort etc. Some companies consider their analysis practise even as a source of competitive advantage since it potentially helps selective decision-making and succeed in setting profitable price level. Business case analysis as a systematical procedure is motivated by an intent to know true business value of potential investment. The procedure includes gathering relevant and trusted data, analysing the data in rational way, calculating predictable business consequences and synthesising the results to the formal business case document. This kind of procedure ignores personal, managerial and orgasational relationships as well as cultural issues which, in turn, may affect strongly to actual analysis in companies. Table 4. illustrates how does business case analysis for rapid productisation position itself in relation to the responding analysis for new product development.

Table 4. Business case analysis for rapid productisation in relation to the analysis for NPD

\begin{tabular}{|c|c|}
\hline Content similarities & Conten \\
\hline 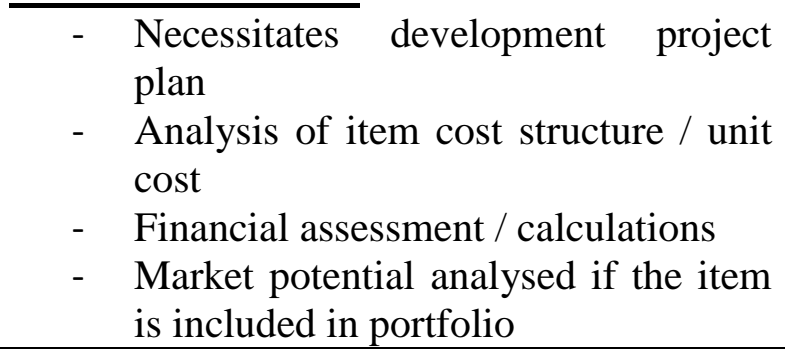 & $\begin{array}{l}\text { - Strategic fit is mainly connected to } \\
\text { the portfolio decision } \\
\text { - Start from a customer-specific need }\end{array}$ \\
\hline $\begin{array}{l}\text { Included only in RP business case } \\
-\quad \begin{array}{l}\text { Include evaluation of sales case and } \\
\text { of customer ship }\end{array} \\
\text { - } \\
\text { Need to analyse whether to include to } \\
\text { product portfolio - strategic fit }\end{array}$ & $\begin{array}{l}\text { Lacking from RP business case } \\
-\quad \text { Technological uncertainties out of } \\
\text { scope } \\
\text { - No delivery capability creation cost } \\
\text { (utilises existing delivery capability } \\
\text { and supplier base) } \\
\text { - No competitor assessment }\end{array}$ \\
\hline
\end{tabular}

In the context of rapid productisation, business case analysis is quite straightforward. Explorative and constructive research approach enables to outline the principal logic and main issues: cost analysis; revenue estimation and strategic fit, for the procedure based on the research data. In Figure 2, we provide an illustrative example of business case analysis procedure for rapid productisation. However, adopting the procedure necessitates careful consideration of the organisation specific and type of business needs. 


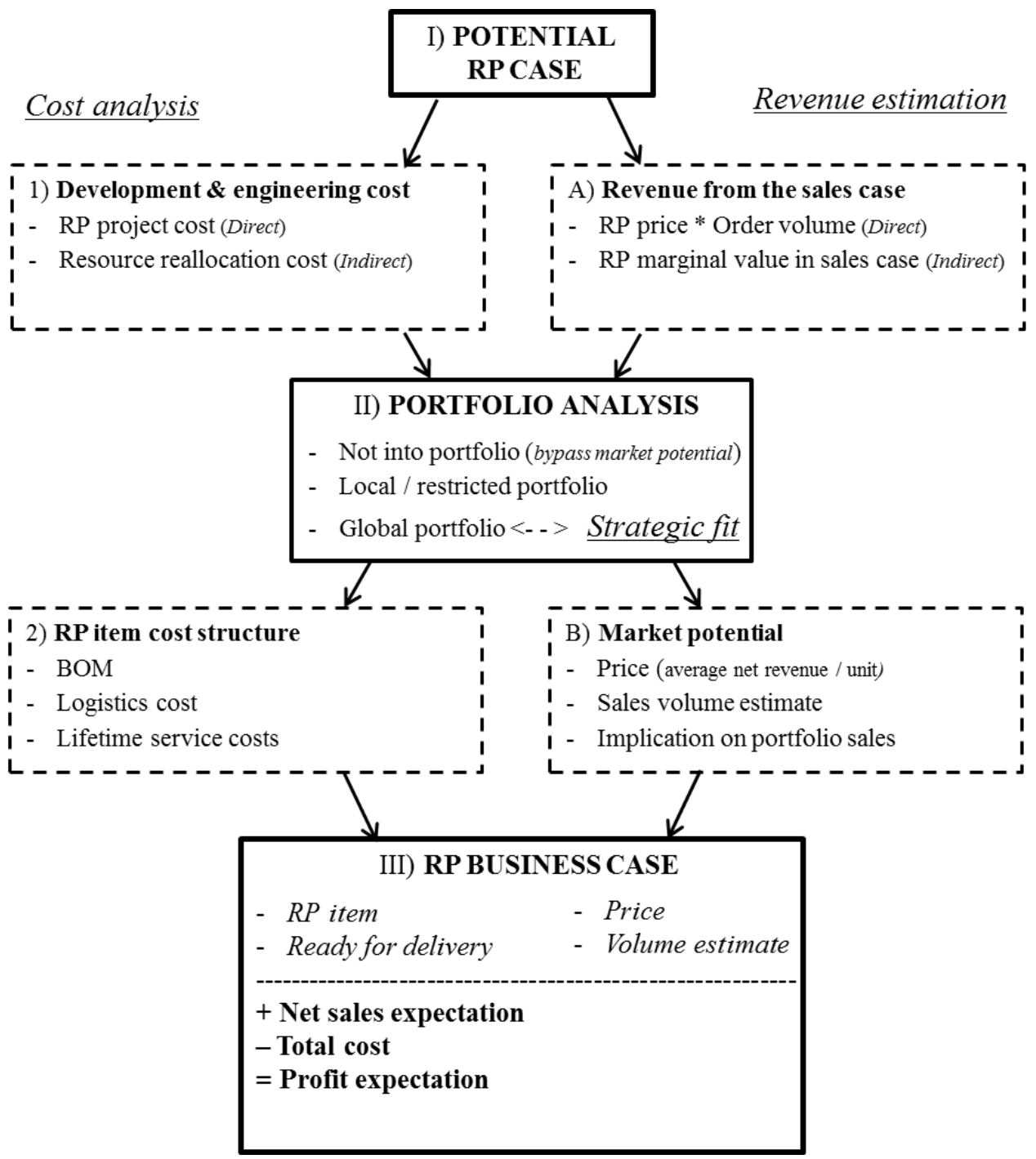

Figure 2. An illustrative example on business case analysis procedure for rapid productisation

In rapid productisation decision-making is culminating in two points: 1) whether to carry out a potential RP case or not, and 2) whether to aim rapid productisation (RP) item only at one customer or at the portfolio. The example procedure flows through two phases. In the first round, a potential RP case is roughly analysed as a RP project to clarify related development and engineering costs. Based on the first-round cost-revenue comparison, the case can be either eliminated or analysed further from portfolio viewpoint. Analysis continues if the RP case includes strategic fit and is aimed at the portfolio. In the second round market potential of RP item is evaluated by predicting sales window and estimating price level and development time, sales volume and impact on portfolio sales. Similarly, the cost structure of RP item from operations and lifecycle viewpoint need to be clarified and calculated. Finally, the estimates from first and second rounds are further synthesised as business case document which by its nature is aiding decision makers to decide whether to carry out the RP case. In case the decision is to carry out rapid productisation, business case serves sales representatives with customer communication, RP project team and product management, and RP item owner or product manager in business planning. 
Seldom companies may face exceptional rapid productisation cases which have very strong impact to the strategy, either as a threat or as a new opportunity. In general, business strategy just guide whether rapid productisation is seen as an acceptable business practice. Productisation carries always risk and business case analysis assists to manage business risks. Risk is present through all the elements and it is not a separate analysis element. Only potential warranty costs include a clear risk that is priced. The warranty costs are associated with lifetime service costs. Risks could be taken into account by calculating different cost and market scenarios (e.g. Otto and Wood, 2001).

Business case analysis drives management to make well-informed decisions. A good question to be discussed is how much effort one should put on business case analysis for rapid productisation. It is challenging task to recognise the trade-off point after which more information would not anymore change the following decision. Furthermore, it is always possible that a strong business case does not lead to success and a weak business case would do. To summarise, analysis, estimation and future prediction includes always risk.

\section{CONCLUSIONS}

Many companies are demanded to offer wide variety of products and services to meet the diverse needs of customers and market. Evolving needs challenge companies' capability to react quickly enough. Rapid productisation can be used to changing or redesigning product modules on the fly to serve sales and order-delivery process.

New product business case analysis is clearly more extensive than the analysis for rapid productisation. For example technological uncertainties, competitive assessment and delivery capability creation cost are not included in business case analysis for rapid productisation. In turn, business case analysis for rapid productisation includes sales case analysis and portfolio analysis which are not part of NPD business case.

Business case of rapid productisation is constructed through revenue estimation, cost analysis and portfolio analysis activities according to our case study. In the first phase sales case is evaluated to estimate the revenue, and project and engineering cost is analysed. In the second phase, if the rapid productisation aims at product portfolio, market potential is analysed to estimate the total revenue, and cost structure of RP item. Finally, all the information and data is synthesised into a business case document which include essentially profit expectation and such RP item basic data as price, ready for delivery date and volume.

The results of this are applicable at least for companies which currently apply the configureto-order delivery mode. Our business case analysis procedure is limited to RP cases which can be as an individual item which may have own business plan. Results of this exploratory case study are not general but need to be applied to the company context considering especially used delivery mode and customer order point. Sales representatives, product managers and researchers interested in productisation may find our findings as benchmark object and could further validate the results in their contexts. Further research would include how to recognise the trade-off point after which more business case information would not change the following business decision. 


\section{REFERENCES}

1. Carbonell-Foulquie, P., Munuera-Aleman, J. L. and Rodriguez-Excudero, A. I., (2004), Criteria employed for go/no-go decisions when developing successful highly innovative products. Industrial Marketing Management, Vol. 33, 307-316.

2. Chung, W. W. C., Ko, C. C. Y., Cheung, E. W. M. and Wong, T. C. W, (2007) "ITenhanced order and delivery process of a fast moving consumer goods (FMCG) company: A case study", Benchmarking: An International Journal, Vol. 14 Iss: 1, pp.123-139.

3. Cooper, R. G., (2001), Winning at New Products: Accelerating the process from idea to launch. Perseus Publishing, Cambridge (Mass.).

4. Cooper, R. G. and Kleinschmidt, E. J., (2007), Winning Businesses in Product Development: The Critical Success Factors. Research Technology Management Vol. 50, No. 3, pp. 52-66.

5. Gautam, N., and Singh, N. (2008), "Lean product development: Maximizing the customer perceived value through design change (redesign)", International Journal of Production Economics. Vol 114, pp.313-332.

6. Hänninen, K., Muhos, M and Haapasalo, H. (2013) "Business Justifications for Rapid Productisation in Small- and Medium -Sized Companies", Technology Innovation and Industrial Management, TIIM 2013 Conference, 29-31 May, 2013, Thailand.

7. Hart, S., Hultink, E. J., Tzokas, N. and Commandeur, H. R., (2003), Industrial companies' evaluation criteria in new product development gates. Journal of Product Innovation Management, Vol. 20, pp. 22-36.

8. Henard, D. H. and Slymanski, D. M., (2001), Why some new products are more successful than others. Journal of Marketing Research Vol. 38, pp. 362-371.

9. Hietala J, Kontio J, Jokinen J and Pyysiainen J (2004) "Challenges of software product companies: results of a national survey in Finland", Proceedings 10th International Symposium on Software Metrics. IEEE: pp. 232-243.

10. Hvam L, Mortensen NH and Riis J (2008) Product customization. New York, Springer.

11. Keen, J. M. and Digrius, B., (2003), Making technology investments profitable: ROI road map to better business cases. Wiley, Hoboken (N.J.).

12. Kinnunen, T., Pekuri, A., Haapasalo, H., and Kuvaja, P. (2011), "Business case analysis in new product development", Global journal of management and business research. Vol. 1 No. 1, pp. 49-56.

13. Koen, P., Ajamian, G., Burkart, R., Clamen, A., Davidson, J., D’Amore, R., Elkins, C., Herald, K., Incorvia, M., Johnson, A., Karol, R., Seibert, R., Slavejkov, A. and Wagner, K., (2001), "Providing clarity and a common language to the "fuzzy front end"". Research Technology Management, Vol. 44, No. 2, pp. 46-55.

14. Kratochvi'1 M and Carson C (cop. 2005) Growing modular: mass customization of complex products, services and software. Berlin, Springer.

15. Randall, W. S., Brady, S. P., and Nowicki, D. R. (2012), "Business case analysis and the confounds of innovation driven by performance-based postproduction support strategies", Transportation Journal. Vol. 51, No. 1, pp. 33-58.

16. Ronkainen, I. A., (1985), Criteria changes across product development stages. Industrial Marketing Management Vol. 14, pp. 171-178.

17. Saaksvuori, A., and Immonen, A., (2008) Product lifecycle management $3^{\text {rd }}$ ed. Berlin, Springer. 
18. Ulrich, K.T. and Eppinger, S.D., (2008), Product design and development 4th ed. McGraw-Hill, Boston.

19. Otto, K.N., and Wood, K.L (2001) Product design: Techniques in reverse engineering and new product development. Upper Saddle River, New Jersey, Prentice Hall. 